\title{
舌癌手術後に発症した移植片対宿主病（GVHD）の１例
}

\author{
金建三・植野茂・梶隆一・島盛隆
}

虫本浩三・白数力也・足立裕康*

\section{A case of GVHD occurring after tongue cancer surgery}

\author{
Kenzo KIN • Shigeru Ueno $•$ Ryuichi Kaji - Moritaka Shim. \\ Kozo Mushimoto $\cdot$ Rikiya Shirasu $•$ Hiroyasu Adachi
}

\begin{abstract}
A case of graft-versus-host discase (GVHD) is presented. The patient was a 26 year-old female with tongue carcinoma. Blood transfusion was performed after the surgical operation.

Although the postoperative period was uneventful, on the 10th day, severe fever, diarrhea, and whole body erythema suddenly appeared. Blood examination disclosed decrease of granulocytes and liver dysfunction. These symptoms increasingly became severe and she fell into acute dyspnea and died. Diagnosis of GVHD was made from these characteristic symptoms and skin biopsy from abdominal erythema.
\end{abstract}

Key words: GVHD (移植片刘宿主病), blood transfusion (輸佔), immunological reaction (免 疫反応)

\section{緒言}

輸血の合併症として輸血後肝炎や AIDSなどの問题 が大きくとりあげられているがそれにもまして重篤 な経過を示すものとして移植片対缩主病 (Graft Versus Host Disease: GVHD) が胸部外科 ${ }^{1 \sim 5)}$ や腹部外科の領 域から報告されている6,7). GVHDは術後安定した状態 から突然発症し, 全身の紅斑や発熱, 下疡, 朋障害, 汎 血球減少，骨髅無形成などを主症状として短期間で死に 至るのが特徵である ${ }^{8)}$

GVHD は最初に骨䯙移植の副作用であるといわれて

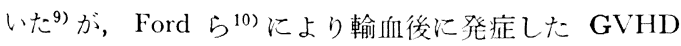
が報告され，輸血によっても発生することがあきらかに なった。 また以前に術後紅皮症として報告されていた症

大阪蔽科大学口腔外科学第 1 㩐座

(主任 : 白数力也教授)

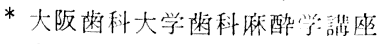

（主任：上田裕教授）

First Department of Oral and Maxillofacial

Surgery, Osaka Dental University (Chief: Prof. Rikiya Shirasu)

* Department of Anesthesiology, Osaka Dental University (Chief: Prof. Yutaka Ueda)
例 ${ }^{11)}$ 马現在では GVH 反応によることが推测されてい 万)

私たちは舌癌患者の于術に伴って輸血を行ったところ

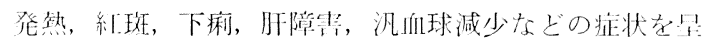

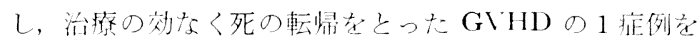
絴駼したので報告する。

\section{症例}

患 者: 26藏 女性.

初診: 昭和63年1月⿴日。

主 訴：左舌縁部接触痛。

家族歴：特咒㭋項なし。

既往歴：初骖の 1 午前より，不婚のために排誘発治 誐を受けていた。

現病歴：初診の1か月前に公舌粶の白玟に気つき，炤

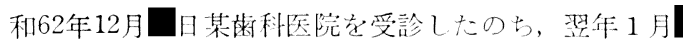
日当科を紹介され来院した。

現 症：全身所見に特記傾はなか力た。

局所所見として左舌縁に大きさ $22 \times 10 \mathrm{~mm}$ の白板症 を伴った潰序があり，周四にわずかな硬結を認めた，接

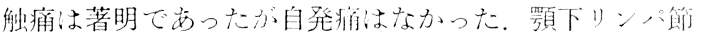
および钼部りン・節に異常は認めなかった。

臨床検査所見：白片球分画でリン・球．６％に低下し 
表 1 臨床檢查

\begin{tabular}{|c|c|c|c|c|}
\hline & 初訩時 & $\mathrm{RT}$ 終了時 & 発熱時 & 第15病日 \\
\hline $\mathrm{RBC}\left(\times 10^{4} / \mathrm{mm}\right)$ & 484 & 448 & 453 & 337 \\
\hline WBC: $\quad(/ \mathrm{mm})$ & 8,100 & 8,200 & 8,400 & 4,600 \\
\hline $\mathrm{Hb} \quad(\mathrm{g} / \mathrm{d} l)$ & 14.4 & 12.7 & 13.7 & 9.5 \\
\hline $\mathrm{Ht} \quad(\%)$ & 40.9 & 38.0 & 39.5 & 28.5 \\
\hline Plt $\left(\times 10^{4} / \mathrm{mm}\right)$ & 26.7 & 31.7 & 17.7 & 16.4 \\
\hline \multicolumn{5}{|l|}{ Hemogram $(\%)$} \\
\hline St. & 6.0 & 6.0 & 13.5 & 40.0 \\
\hline Seg. & 73.0 & 78 & 80.0 & 53.5 \\
\hline E. & 1.0 & 1.0 & 1.0 & 0.0 \\
\hline B. & 0 & 0 & & 0.5 \\
\hline Ly. & 14.0 & 6 & 2.0 & 3.5 \\
\hline Mono. & 6.0 & 9 & 3.5 & 0.5 \\
\hline GOT (U) & 21 & 18 & 61 & 1,561 \\
\hline GPT (U) & 14 & 13 & 65 & 684 \\
\hline$\gamma$-GTP (U) & 15 & 12 & 38 & 150 \\
\hline BUN $(\mathrm{mg} / \mathrm{d} l)$ & 11 & & 12 & 21 \\
\hline
\end{tabular}

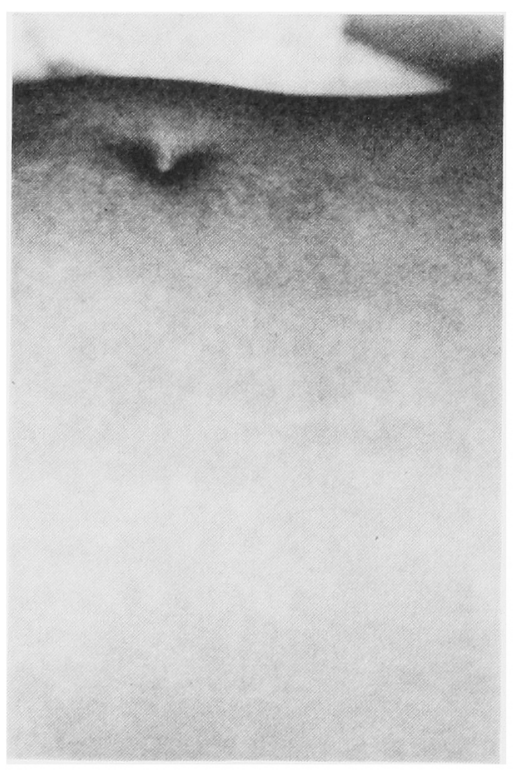

写直 1 腹部の紅斑

紅斑は最初麻疹状の小発疹であったが， 次第に瘾合し，全体に発赤した状態に なっった。

ていたが，その他に異常はなかった（表1）。

臨床診断：舌癌 (T 2 NOMO).

病理組織診断：角化片平上皮癌.

処置および䅅過：炤和63年 1 月日日，生検に上り上記 診断を得たため，たたらに治療を開始した。 ${ }^{\circ 0} \mathrm{Co} 50 \mathrm{~Gy}$
の術前照射, CDDP $80 \mathrm{mg}$ の静注 および Sizofilan 計 $40 \mathrm{mg}$ の筋注を行ったのち，同年 4 月曰日，左頸部部清 術, 左舌半側切除お゙よ゙゙大胸筋皮并による即時再建術を

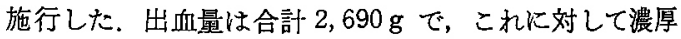
赤血球 $2,000 \mathrm{~g}$ および涷結血漿 $800 \mathrm{~g}$ を輸血した，その 後順調に経過していたが，輸血後10日目に $39^{\circ} \mathrm{C}$ を越之 る熱発が現われ，翌日には全身の紅斑様発疹および下峲 が出現した，紅斑は術後11日目に右上肢に麻疹様の小さ な発疹としてあらわれ，その後大きさを增して互いに療 合しながら四肢拈よび 全身に広がった（写真 1)。紅斑

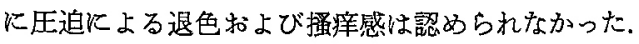

発熱はさらにつつき，抗生物質の変更にも反応せず $39^{\circ} \mathrm{C}$ を越える高熱がつづいた，血液培養検查は陰性で あった，兔废グロブリン製剤(ヴェノグロブリン１）， および抗ヒスタミン剤を投与したが奏功せず，さらに肝 機能の低下が進行して, 術後15日目に急性呼吸不全のた め死の転帰をとった（表 2 ）。

紅斑部皮瓜の病理組織学的所見: 紅斑が出現して 2 日 目に，腹部紅斑の皮廂生検を行った。病理組織学的には 表皮の剝離，梀細胞および基底細胞の空胞化がみられ， 表皮内拈よび表皮下に著しいリンパ球の浸潤が観察され た (写真 2). これらを免疫組織学的に観察すると，リ ン八゚球の大部分は T細胞で， B 細胞はほとんど認められ なかった（写直了）。

考察

GVHD の発生頻度はあきらかではないか゚, Mylhre 
表 2 手術後の臨床経過

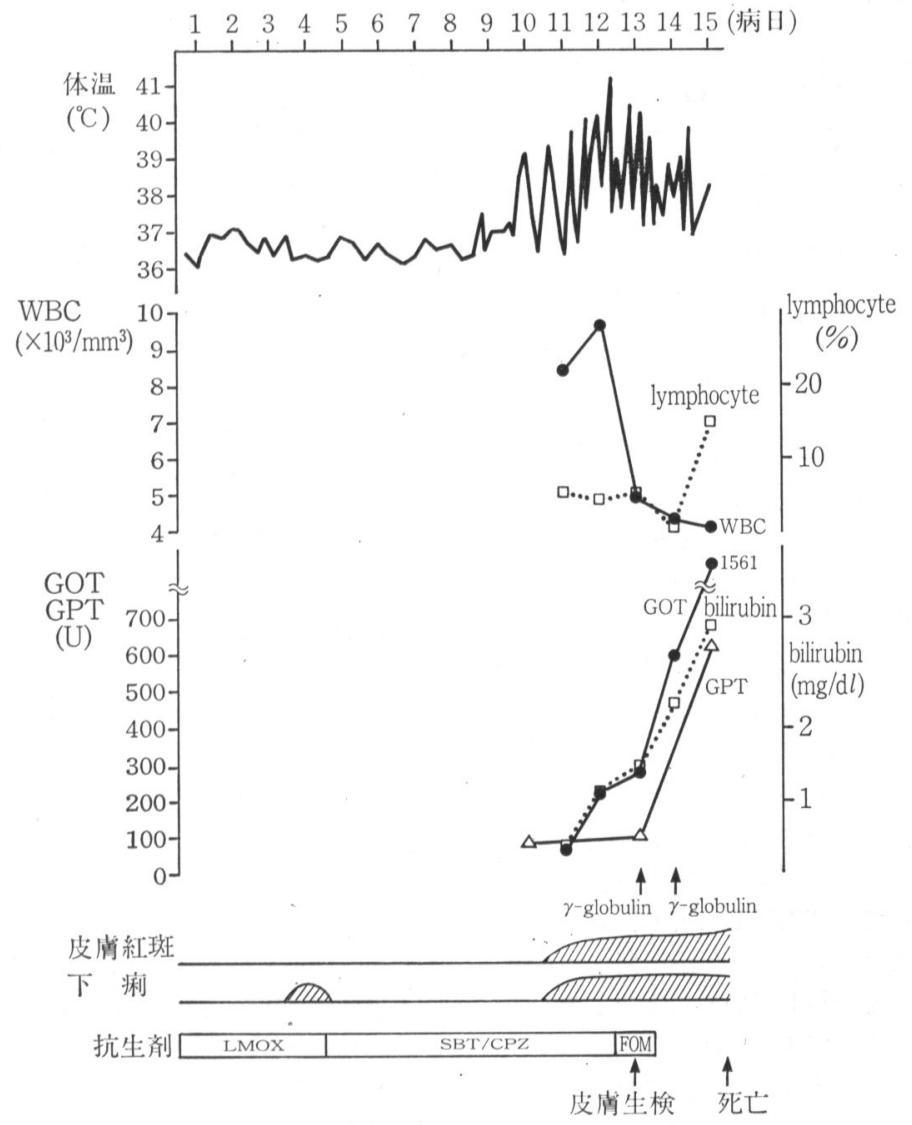

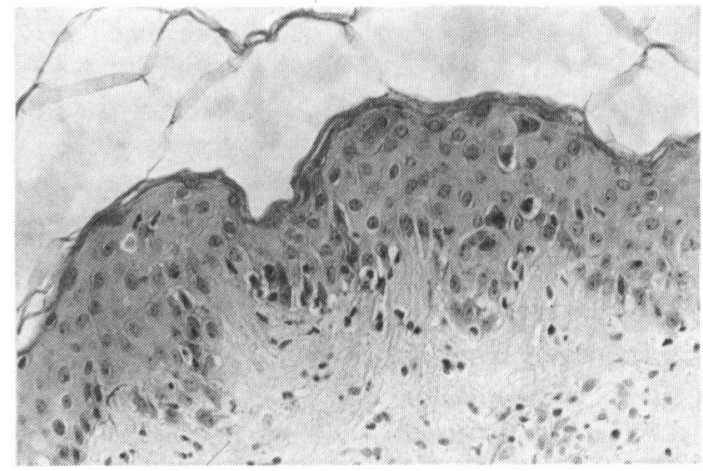

写真 2 紅斑の病理組織像

皮上組織に多数のリンパ球がみられ，それらが上皮 内にも浸潤している。基底細胞や棘細胞の一部は空 胞化し, 表皮の䐣離子認められる（H-E 染色, $\times$ 200)

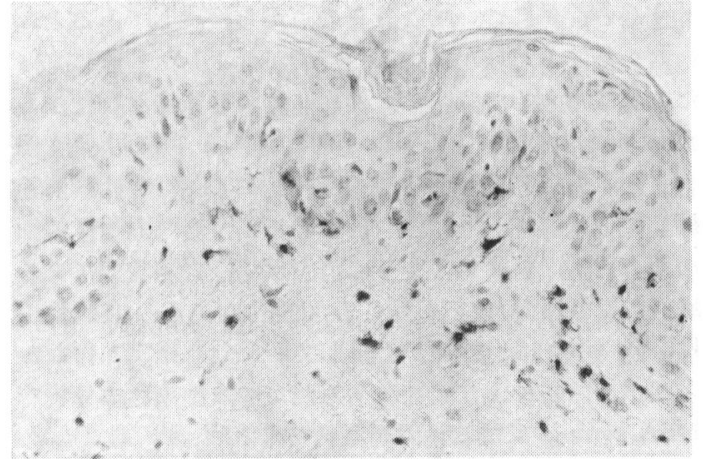

写真 3 紅斑の免疫組織学的染色像 皮下抒よび上皮内に浸潤したリンパ球はすべて $\mathrm{T}$ 細 胞である（抗 $\mathrm{T}$ 細胞抗体染色, $\mathrm{ABC}$ 法). 
の臨床統計では, 輸血による死亡战77例中 GVHDに よるものは1例であったと報告されており，きおわてま れなものであると考えられる。 GVHDは臨床的に急性 型と慢性型に分類されるが，輸血後のGVHDはほとん どが急性型の経過をたどる。予後はきわめて悪く, 死亡

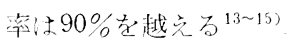

GVH 反応とは輸血中心含まれている T細胞 (graft) が host の組織中ア口抗原（特に HLA 抗原）支㤎識し

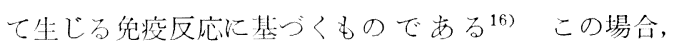
反応の初期におけるア口抗原の諗識には graft CD $4^{+}$ (helper T 紐胞) が重装な役制を担って捄り，そのシグ ナルを受けて graft CD 8+ (cytotoxic $\mathrm{T}$ 緗胞) が強力 に誘導されることがあさらかになっている ${ }^{16)}$. そしてこ

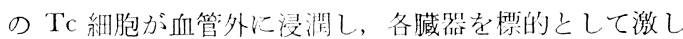
く攻整を始めるわけであるが，破繦した host の免疫抑 制機满によって Tc 細胞の細胞賃责作用は一段と增強さ れると考えられている17)

GVHD は，免疫不全傾问にある患者に対して大量の 白血球を移㥀したときに起こる可能性が高く ${ }^{9)}$, 化学療 法に上る骨能抑制状態や感染定によってりン・球が減少 状態にある場合に，GVHD 発拝の危険性:は增加する と報告されている18,19)，Reinherz ら ${ }^{20)}$ によると，急性 GVHD では末梢血中の suppressor $\mathrm{T}$ 細胞が消失する が，病気の回復に先だって再び出現してくる．このこと は，GVHD の発症には cytotoxic T 紐胞に刘する抑制 が阻書されることが大きく関与していることを示㗪して いる。幸道ら ${ }^{21)}$ は輸血によって GVHD 反応が起こりう る危俩因子として，(1)宿主が免疾不全状態にあること， (2)䔟植沜中に免疫担当緗胞（主にリンパ球）が多咞に存 作すること，3宿主と移椎片の組織適分抗原 (HLA) が 合致していないことなどをあけ゚ている。

今回の症例についてこれらの点から椿討してみると, 術前からリン・球が減少し免疫能が低下した状態に市。 たことはあきらかである。輸血には濃厚赤血球を使用し たが，滥厚赤血球中にリンハ球は $400 \mathrm{~g}$ 中に $1 \times 10^{9}$ 個 含まれるといわれている22)。一般的に GVHDは新鮮向 蝓血の合僧症として報告されているが，滥厚赤血球輸血 の場合でも，自駼例のように宿主が免疫抑制状態にある 場合には GVH 反応が起こる可能性がある。自駼例の HLA typingは，顺体が不足していたため確定し得なか

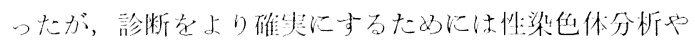
IILA typing による检㨽が必恶である23)

HLA 抗原は赤血球には汪とんどみられず，白血球に 多是に存在才る。これらはヒトの主要組䄉咕合抗原をい

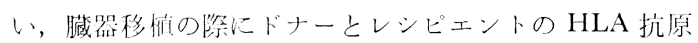

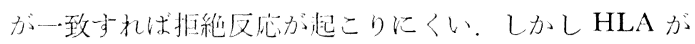
一致しているにもかかわらず GVHD が発症した症例

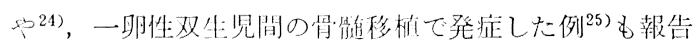
されて扣り，HLA 抗原以外にも GVHD の発症图子が
存在する可能性が示唆されている ${ }^{26)}$. 現在も GVHDの 病因については不明の点も多く，今後の検討を必要とす る.

また，皮脂生検による病理組織学的診断もGVHDの 診断にはきわめて有用である211。紅斑部における初期の 病理組織学的变化は，真皮上層の血管周囲にみられる円 形細胞浸潤として現れる。主としてリンパ球からなるこ の紐胞浸潤は，早期注ど軽度である。リンパ球の浸潤 は経時的に著明となり，それと密接に闺連して表皮の spongiosis や表皮角化紐胞の異常角化，さらには基底緑

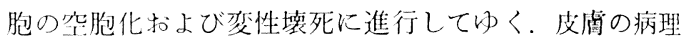
組織学的変化の程度は Lerner ら 27 によって分類されて 扣り，自験例は grade Iであった。 GVHD に関与する

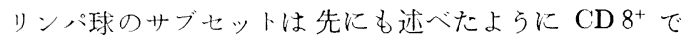
あるが，自験例に扮いても丁細胞が浸潤の主体を占めて いた ${ }^{17,28)}$

急性 GVHD 患者を数命するためには一刻を争ら処狊 が必要となり，初期の臨木像から的確に判断することが 要求される。しかし症例自体がきわめてまれなため臨床 例を経駼するることが少なく、診断は困難である。特に劇 症肝炎，败血症などと類似した症状を示し，鑑别を要寸 子.

剧症肝炎も輸血後発症例が多く，トランスアミラーゼ の上昇など，急速な肝機能の低下をきたす点で GVHD と共通している。しかし GVHDにみられるような紅斑 は出現せず，HBs 抗原が30〜45\%の症例で陽性になる ことから鑑別が可能である。

また敗血症は湤しい弛張熱を示し，点状出血や紅斑な ぞの皮革症状がみられることで鑑别が必要になるが30),

下脷や肝機能低下などの点で区別しらる。

治療法としてはステロイドの投与，顆粒球輸血，罠㵦 移析、，肝比榄剂および抗アレルギー剂の投与などが乲功 したといら報告》がみられるが，有効な治療法であると はいい難い。自㪘例でも抗生剂の変更, 朋庇蓝剤および 抗ヒスタミン剤などの投与を行ったが奏功しなかった。 現在のところ GVHD の治療法は確立されて拉らず, む しろ子防に力を注ぐしかないというのが現状である。輸 㿼を行らにあたってはできるだけ自家助を使らか，保存 血を使ら場合には血液に対して 15〜50 Gy の放射線照 射を行って拈くことが望ましい31 33).

\section{結語}

舌嵒手術に伴ら保存血輸血後11日目に発熟扣よび全身 の紅斑を生じ，さらに顆粒球減少，肝機能低下などによ り死の転师をとった症例について報告した，本症例は特

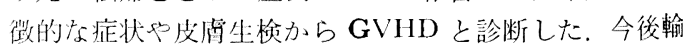
血を施行するにあたり，予防処掅を含めて十分な対処の 必要性を痛感した。 
本症例の暏断扣よび治療に際して有益なご助言を戴い

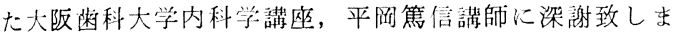
与。

本論文の要旨は，第34回日本口腔外科学会棇会（1989 年10月27日, 郡山）に沶いて発表した。

\section{引用文 献}

1) 西田博, 河村剛史, 他：A-C ヘ イ 々 久術後, いわゆる術後紅皮症を是した 1 例。胸部外科 34: 62-65 1981.

2）保浦䝨三，安間文应，他：心缄于術後に発生し た術後紅皮症，病理所見よりみた問题点。胸部 外科 37：895-899 1984.

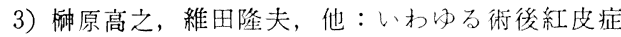
5 症例の検討.日心血外会誌 16:210-212 1986 .

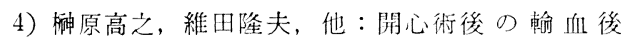
GVHD, リンパ球 HLA タイピングと皮有生 検から術後紅皮症の病因と確診し得た 2 経験 例。日胸外会誌 36：176-183 1988 .

5) Thaler, M., Shamiss, A., et al.: The role of blood from HLA homozygous donors in fatal transfusion-associated graft-versus-host disease after open-heart surgery. N Engl J Med 321: 25-28 1989.

6) 青木泰子, 中村治雄, 他: 腹部大動脈瘤手術後 の翰血による移植片対宿主反応が疑われた高秢 者の 1 例。 日内会誌 73：99-106 1984 .

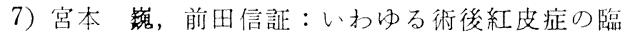
床。外科 48: 871-874 1987 .

8) 井野隆史, 松浦昭堆, 他: 手術時の輸血に上る GVHD 様症候群。外科 48：706-712 1987.

9) Hathaway, W.E., Githens, J.H., et al. . Aplastic anemia, histiocytosis and erythrodermia in immunologically deficient children. N Engl J Med 273: 953-958 1965.

10) Ford, J.M., Lucey J.J., et al.. Fatal graftversus-host disease following transfusion of granulocytes from normal donors. Lancet 2: 1167-1169 1976.

11）霜田俊丸：術後紅皮症について。外科 17:4874921955.

12) Myhre, B.A.: Fatalities from blood transfusion. JAMA 244: 1333-1335 1980.

13) Brubaker, D.B.: Transfusion-associated graftversus-host disease. Human Pathology 17: 1085-1088 1986.

14) Holland, P.V.: Prevention of transfusion-associated graft-vs-host disease. Arch Pathol Lab Med 113: 285-291 1989.

15）井野隆史：開心街後に扮汸る榆血によるGVHD 症假群。 Immunohaematology 9: 133-138 1987.

16）池澤善郎：輸血による GVH 反応の皮痛病変.
外科 49:884-893 1987.

17）宮地良檄，藤由真由美，他：小わ的術後紅皮 症を呈した GVHDの2 例。皮店臨本 30:4494521988.

18) Dinsmore, R.E., Straus, D.J., et al.: Fatal graft-versus-host disease following blood transfusion in Hodgikin's disease documented by HLA typing. Blood 55: 831-834 1980.

19) Labotka, R. J. and Radvany, R.: Graft-versushost disease in rhabdomyosarcoma following transfusion with non-irradiated blood products. Medical and Pediatric Oncology 13: 101-104 1985.

20) Reinherz, E.L., Parkman, R., et al.: Aberrations of suppressor $\mathrm{T}$ cells in human graftversus-host disease. N Engl J Med 300: 1061-1067 1979.

21）幸道秀樹，浅野茂隆：翰血によるGVHRとそ の対筑。免疼と血液 7: 143-148 1985 .

22）井野隆史：輸血による GVH 反応の実態一とく に手術洔輸血に上る GVHD 㥞症候群一。外科 49: 875-883 1987.

23) Siimes, M.A. and Koskimies, S.: Chronic graft-versus-host disease after blood transfusions confirmed by incompatible HLA antigens in bone marrow. Lancet 1: 42-43 1982.

24) Starke, I.D., Thein, S.L., et al.: Graft-versushost disease after treatment for chronic granulocytic leukaemia in transformaiton. $\mathrm{Br} \mathrm{J}$ Haematol 52: 383-387 1982.

25) Rappeport, J., Mihm, M., et al. . Acute graftversus-host disease in recipients of bone-marrow transplants from identical twin donors. Lancet 2: 717-720 1979.

26) Halle-Pannenko, O., Pritchard, L.L., et al.: Parameters involved in the induction and abrogation of the lethal graft-versus-host reaction directed against non $\mathrm{H}-2$ antigens. Immunological Reviews 88: 59-85 1985.

27) Lerner, K.G., Kao, G.F., et al. Histopatho$\log y$ of graft-vs.-host reaction $(\mathrm{GvHR})$ in human recipients of marrow from HL-Amatched sibling donors. Transplant Proc 4: 3673711974.

28) Farmer, E.R.: Human cutaneous graft-versushost disease. J Invest Dermatol 85: $124 \mathrm{~s}-$ 128 s 1985.

29）鎌田武信：図説内科䛦断治療諈坐 5 旰炎, 旰 硬変, 旰癌。メジカルビュ一社, 東京, 1988, 102-111頁.

30）中尾喜久, 山形敞一, 他: 内科学書第 1 卷. 中 山書店, 東京, 1982, 668-812頁.

31) Weiden, P.L., Zuckerman, N., et al.: Fatal graft-versus-host disease in a patient with lymphoblastic leukemia following nomal granulocyte transfusions. Blood 57:328-332 1981. 
32) Button, L.N., DeWolf, W.C., et al.: The effects of irradiation on blood components. Transfusion 21: 419-426 1981.
33) 柴田 治, 冨安志郎, 他: 輸血後 GVHD. 臨 床底酔 14：239-243 1990 . 